Louisiana State University

LSU Digital Commons

Faculty Publications

Department of Biological Sciences

$12-1-2015$

\title{
Multitrophic enemy escape of invasive Phragmites australis and its introduced herbivores in North America
}

\author{
Warwick J. Allen \\ Louisiana State University \\ Randee E. Young \\ Louisiana State University \\ Ganesh P. Bhattarai \\ Louisiana State University \\ Jordan R. Croy \\ Louisiana State University \\ Adam M. Lambert \\ University of California, Santa Barbara
}

See next page for additional authors

Follow this and additional works at: https://digitalcommons.Isu.edu/biosci_pubs

\section{Recommended Citation}

Allen, W., Young, R., Bhattarai, G., Croy, J., Lambert, A., Meyerson, L., \& Cronin, J. (2015). Multitrophic enemy escape of invasive Phragmites australis and its introduced herbivores in North America. Biological Invasions, 17(12), 3419-3432. https://doi.org/10.1007/s10530-015-0968-2

This Article is brought to you for free and open access by the Department of Biological Sciences at LSU Digital Commons. It has been accepted for inclusion in Faculty Publications by an authorized administrator of LSU Digital Commons. For more information, please contact ir@lsu.edu. 


\section{Authors}

Warwick J. Allen, Randee E. Young, Ganesh P. Bhattarai, Jordan R. Croy, Adam M. Lambert, Laura A. Meyerson, and James T. Cronin 


\title{
Multitrophic enemy escape of invasive Phragmites australis and its introduced herbivores in North America
}

\author{
Warwick J. Allen · Randee E. Young • Ganesh P. Bhattarai • \\ Jordan R. Croy • Adam M. Lambert • Laura A. Meyerson • \\ James T. Cronin
}

Received: 30 December 2014/Accepted: 19 August 2015/Published online: 28 August 2015

(C) Springer International Publishing Switzerland 2015

\begin{abstract}
One explanation for why invasive species are successful is that they escape natural enemies from their native range or experience lower attack from natural enemies in the introduced range relative to native species (i.e., the enemy-release hypothesis). However, little is known about how invasive plants interact with co-introduced herbivores or natural enemies of the introduced herbivores. We focus on Phragmites australis, a wetland grass native to Europe (EU) and North America (NA). Within the past 100-150 years, invasive European genotypes of $P$. australis and several species of specialist Lipara gall flies have spread within NA. On both continents we
\end{abstract}

Electronic supplementary material The online version of this article (doi:10.1007/s10530-015-0968-2) contains supplementary material, which is available to authorized users.

W. J. Allen $(\bowtie) \cdot$ R. E. Young · G. P. Bhattarai ·

J. R. Croy · J. T. Cronin

Department of Biological Sciences, Louisiana State

University, Baton Rouge, LA 70803, USA

e-mail: warwick.j.allen@gmail.com

\section{A. M. Lambert}

UCSB Marine Science Institute, University of California at Santa Barbara, Santa Barbara, CA 93106, USA

\section{A. Meyerson}

Natural Resources Science, University of Rhode Island,

Kingston, RI 02881, USA surveyed $P$. australis patches for Lipara infestation (proportion of stems infested) and Lipara mortality from natural enemies. Our objectives were to assess evidence for enemy-release in the invaded (NA) versus native (EU) range and whether Lipara infestation or mortality differed between invasive and native $P$. australis genotypes in NA. Enemy-release varied regionally; Lipara were absent throughout most of NA, supporting enemy-release of Phragmites. However, where Lipara were present, the proportion of invasive $P$. australis stems infested with Lipara was higher in the introduced $(11 \%)$ than native range $(<1 \%)$. This difference may be explained by the absence of Lipara parasitoids in our NA survey, strongly supporting enemy-release of Lipara. In NA, native $P$. australis genotypes exhibited higher Lipara infestation (32\%) than invasive genotypes (11\%), largely driven by $L$. rufitarsis. We attribute genotypic differences in infestation to a combination of Lipara exhibiting $34 \%$ greater performance (gall diameter) and suffering four times less vertebrate predation on native than invasive genotypes. Our study suggests that complex interactions can result from the cointroduction of plants and their herbivores, and that a multitrophic perspective is required for investigating how biotic interactions influence invasion success.

Keywords Biotic resistance $\cdot$ Chloropidae $\cdot$ Enemy release · Invasive plants - Invasional meltdown . Lipara spp. natural enemies 


\section{Introduction}

A widely supported explanation for the success of invasive species is that they leave behind their coevolved natural enemies (e.g., herbivores and pathogens) when introduced to a new environment (e.g., Wolfe 2002; Mitchell and Power 2003; Liu and Stiling 2006; Castells et al. 2013), a phenomenon known as enemy-release (Elton 1958; Keane and Crawley 2002). An extension of this hypothesis, known as local enemy-release (Zheng et al. 2012), predicts that invasive species also suffer less damage from natural enemies in the introduced range compared to co-occurring, closely related native species (e.g., Dietz et al. 2004; Parker and Gilbert 2007; Cincotta et al. 2009; Funk and Throop 2009; Zheng et al. 2012; Cronin et al. 2015). This result may be driven by the inability of non-coadapted natural enemies to overcome the novel defenses of invasive species, greater palatability and nutritional quality of native species, or subtle differences in microhabitat. In contrast to the concept of enemy-release, the bioticresistance hypothesis (Elton 1958; Parker and Hay 2005) predicts that natural enemies in the introduced range cause more mortality to invasive species than co-occurring, closely related native species (e.g., Agrawal and Kotanen 2003; Chun et al. 2010; Morrison and Hay 2011; Fan et al. 2013). This phenomenon is often attributed to the invasive species lacking effective defenses to resist attack by natural enemies with which they do not share an evolutionary history (Morrison and Hay 2011).

A complicating factor of both the enemy-release and biotic-resistance hypotheses is that herbivores from the region of origin of the invasive plant could also be accidentally or intentionally introduced with their invading host plant. Such a scenario does not strictly fit with both hypotheses because the introduced herbivores are presumably already coadapted with the invasive plant and are not native to the recipient community. In the novel environment, the interaction between the invasive plant and introduced herbivore species could be significantly different from in their native range. For example, herbivory of invasive plants by introduced herbivores could be greater in the introduced than native range. Although lower herbivory in the introduced than native range would not represent enemy-release sensu stricto, the resulting advantages to the invasive plant are likely the same. Moreover, novel indirect interactions can potentially lead to net positive effects of herbivory for the invasive host plant in the introduced range (e.g., indirect dispersal through seed predators, see Pearson et al. 2000; Pearson and Ortega 2002), known as the enemy inversion hypothesis (Colautti et al. 2004).

Although tritrophic interactions have received little attention in invasion biology (Harvey et al. 2010), the strength of enemy-release or biotic-resistance may be influenced by higher trophic levels (i.e., predators and parasitoids). Differences in mortality due to natural enemies may represent an explanation for why herbivory varies between invasive and native plants, and between native and introduced ranges. Introduced herbivores may escape their own natural enemies (i.e., enemy-release), allowing them to become more prevalent on host plants in the new range (e.g., Menéndez et al. 2008; Prior and Hellmann 2013). Alternatively, if herbivores feeding on invasive plants suffer greater native natural enemy pressure than those feeding upon closely related native hosts (e.g., Engelkes et al. 2012), this could benefit the invasive plant species through reduced herbivory (i.e., a trophic cascade).

The goal of this study was to assess the evidence supporting enemy-release and biotic-resistance at multiple trophic levels involving the common reed, Phragmites australis (Cav.) Trin. ex Steudel (Poales: Poaceae), monophagous gall-forming flies in the genus Lipara Meigen (Diptera: Chloropidae), and their natural enemies. Invasive European genotypes of $P$. australis widely overlap with the distribution of rare native genotypes in marshes and wetlands of North America (NA) (Saltonstall 2002). Lipara spp. are also introduced from Europe (EU) into NA. To date, there is little information on Lipara and their natural enemies in NA. The exceptions are the studies by Lambert et al. (2007) and Park and Blossey (2008) which found evidence suggesting Lipara infestation is higher on native than invasive genotypes. However, these studies were based on a comparison of three native and 16 invasive $P$. australis patches from the northeastern United States.

We surveyed 143 P. australis patches throughout NA and 21 patches along the Atlantic coast of EU to determine Lipara presence, infestation level (proportion of stems infested), performance (gall diameter and 
adult dry body mass), impact (stem height and flowering frequency), and mortality due to parasitoids and predators. Based on enemy-release and invasion theory, we made the following predictions: (1) infestation of Lipara on P. australis would be lower in the introduced (NA) compared to native (EU) range (i.e., enemy-release for the plant); (2) Lipara infestation, performance, and impact would be lower on invasive relative to native genotypes of $P$. australis in NA (i.e., local enemy-release); and (3) mortality of Lipara due to vertebrate and invertebrate natural enemies would be lower in NA than in EU, and on native than invasive genotypes in NA (i.e., enemy-release for the herbivore).

\section{Materials and methods}

Study organisms

Phragmites australis is a $2-5 \mathrm{~m}$ tall macrophytic grass commonly found in wetlands, rivers, salt marshes, and estuaries on every continent except Antarctica (Clevering and Lissner 1999). Although P. australis has been present in NA for millennia (Hansen 1978; Orson 1999), it has spread rapidly during the past 150 years. This spread has been attributed largely to the cryptic invasion of multiple invasive genotypes (Hauber et al. 2011; Howard et al. 2008; Lambertini et al. 2012; Meyerson and Cronin 2013; Saltonstall 2002; for review, see Meyerson et al. 2012), which have had profound ecological impacts, altering hydrology, ecosystem function, and degrading habitat for native species (Saltonstall 2002; Meyerson et al. 2000, 2009). The most abundant and widespread invasive genotype is known as $M$ (based on an analysis of chloroplast DNA; Saltonstall 2002), which derives from EU and Asia. There are other introduced genotypes from Europe (e.g., L1 genotype; Meyerson and Cronin 2013) and we lump them all together as European invasive genotypes. Along the Gulf Coast of LA, there are also multiple non-native genotypes (Lambertini et al. 2012; Meyerson et al. 2012) and some are spreading rapidly (Bhattarai and Cronin 2014), the most common of which is known as genotype I. Finally, at least 14 native genotypes have been identified in NA (Saltonstall 2002; Meadows and Saltonstall 2007; Vachon and Freeland 2011), which we collectively refer to as "native genotypes" in our analyses. Because herbivory of invasive species has been shown to decrease with greater taxonomic isolation from the resident native community (Dawson et al. 2009; Hill and Kotanen 2009), our study provides a strong and conservative test of the enemy-release and biotic-resistance hypotheses by using distinct native and invasive lineages within a single species.

$P$. australis is host to a high diversity of arthropod herbivores in EU, where over 170 different species have been identified (Tewksbury et al. 2002). In NA, specialist native herbivores are scarce (Tewksbury et al. 2002) although generalists are common (Cronin et al. unpublished data). However, the majority of herbivore damage is attributed to arthropods accidentally introduced to NA, including three species of Lipara: L. pullitarsis Doskocil and Chvala, L. rufitarsis Loew, and L. similis Schiner (Tewksbury et al. 2002; Cronin et al. 2015). The genus Lipara is native to EU and northern Asia and all eleven species are monophagous on P. australis (Grochowska 2013). Lipara are univoltine and a single fully-grown larva overwinters inside the senesced stem. Pupation occurs in the spring, followed shortly thereafter by adult emergence. Once mated, females oviposit on young $P$. australis shoots (Chvala et al. 1974; Reader 2003). Larvae feed internally and generally cause internodes to shorten, widen, and become engorged with nutritious parenchymatous tissue (De Bruyn 1995). Infestation of a stem is associated with strong negative effects on flowering and stem height (Lambert et al. 2007).

Four species of Lipara are present in EU where $P$. australis genotypes $M$ and L1 are native: L. lucens Meigen, L. pullitarsis, L. rufitarsis, and L. similis. Lipara infestation levels (proportion of stems infested) in EU are variable; generally less than $5 \%$ of $P$. australis stems are attacked (Reader 2001; Schwarzlander and Hafliger 2000; Skuhravy 1981), although rare outbreaks of infestation levels up to $46 \%$ were reported in a survey of 19 patches over multiple years (Schwarzlander and Hafliger 2000). Moreover, Lipara galls in EU are frequently attacked by a high diversity of parasitoids (Nartshuk 2006) and depredated by the harvest mouse (Micromys minutus) and blue tit (Cyanistes caeruleus) (Mook 1967; Reader 2001; Nartshuk 2007).

Three, and possibly all four, of the EU Lipara species have been introduced into NA. L. lucens was identified by Sabrosky (1958) from specimens collected in Connecticut in 1931, but neither the original 
specimens nor any subsequent records are available. $L$. similis was likely introduced in New Jersey via packing material from Holland in 1946 (Sabrosky 1958), while the earliest records for $L$. rufitarsis and L. pullitarsis are from Rhode Island in 1998 and New Jersey in 2002, respectively (Tewksbury et al. 2002). To date, investigations of Lipara in the northeastern United States report infestation levels to be as high as $80 \%$ (Balme 2000; Blossey 2003; Lambert et al. 2007; Park and Blossey 2008). L. pullitarsis was reported as restricted to the invasive genotype (Blossey 2003), whereas both L. rufitarsis and L. similis have been found inhabiting native and invasive genotypes, with some evidence suggesting they prefer the former (Lambert et al. 2007; Park and Blossey 2008). Furthermore, based on the frequency of damage and the direct impact on sexual reproduction, Cronin et al. (2015) suggested that Lipara represent one of the most damaging and important $P$. australis herbivore groups in North America. At present, there is no information on Lipara natural enemies in NA.

Study sites

We examined $143 P$. australis patches throughout NA and 21 patches in Western EU (Fig. 1, Online Resource 1, Online Resource 2) for the presence of
Lipara galls, as part of a broader herbivore survey (Cronin et al. 2015). Sampling effort in NA was concentrated along the East Coast (where $M$ first appeared in herbarium records ca. 150 years ago), the Mississippi River Valley extending from Louisiana to northern Minnesota, and the Western United States. A total of $48 \mathrm{M}, 1 \mathrm{Ll}$ (a recently identified invasive genotype in Canada; Meyerson and Cronin 2013), 19 $I$, and 75 native genotype patches were sampled between 2011 and 2014. Patches of different genotypes often occurred in the same watershed but were rarely intermixed. In EU, patches (all genotype $M$ ) were selected to complement the geographic range of those in NA. Leaf material from each patch was collected for later determination of genotype (based on chloroplast DNA) using the methods of Saltonstall (2002) but with modifications outlined in Kulmatiski et al. (2010).

\section{Data collection}

\section{Lipara distribution and infestation level}

All $P$. australis patches were inspected by a team of 2-4 investigators for the presence of Lipara galls. The minimum inspection period was 5-10 $\mathrm{min}$, but if Lipara appeared absent or scarce, 30-60 min was

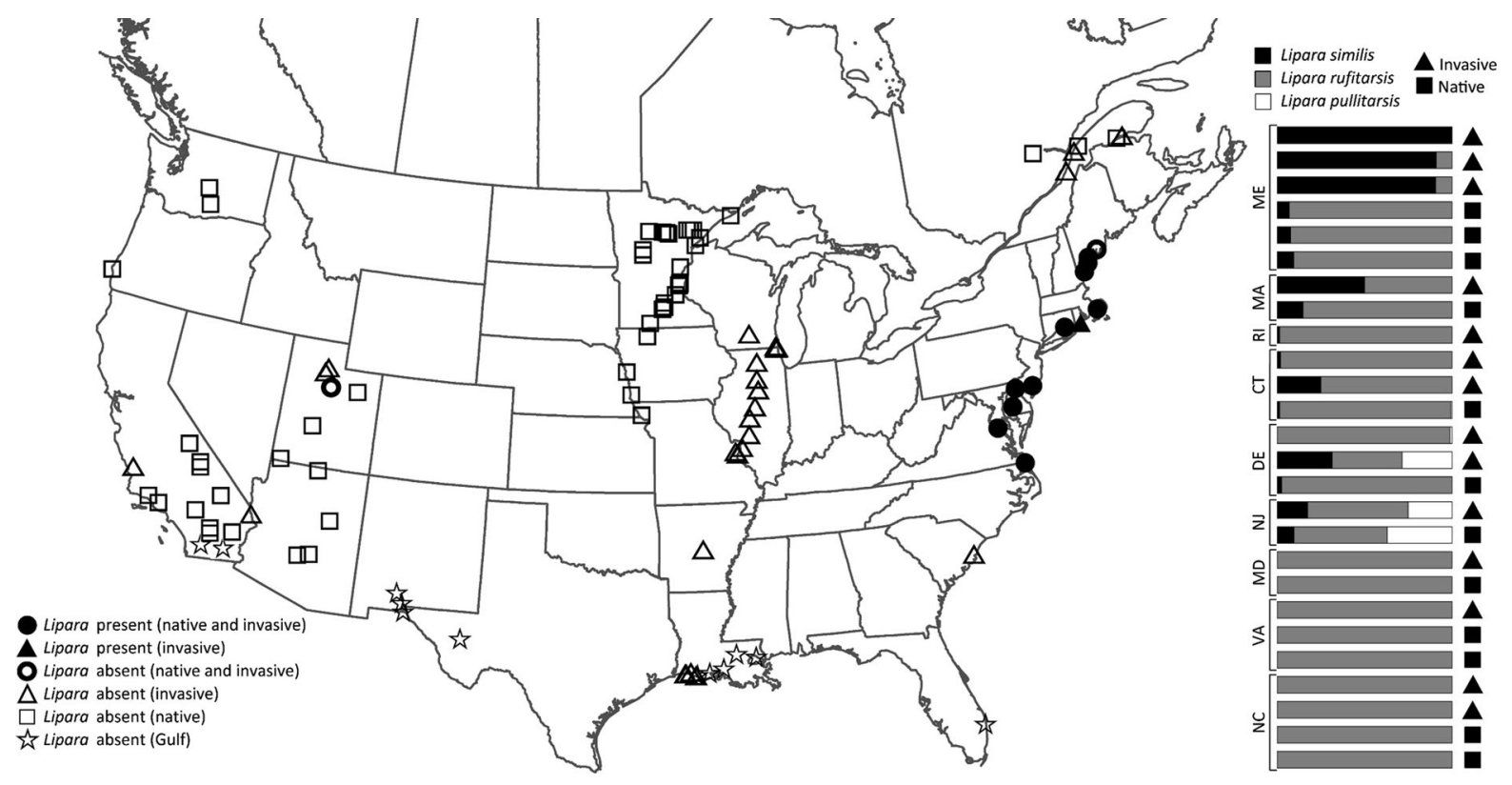

Fig. 1 Phragmites australis sampling sites and the distribution of Lipara species in North America. The relative abundance (proportion of collected stems inhabited by each Lipara species) of Lipara species is shown for patches occupied by Lipara 
spent searching the patch to confirm presence or absence and to maximize gall collection for the study. Sampling in NA was conducted during four different seasons: summer 2012 (July 31-August 20), winter 2013 (March 1-April 20), summer 2013 (August 1-24), and summer 2014 (August 17-26). Most patches were only sampled once, but some were sampled on a second occasion to collect overwintering galls (Online Resource 2). EU patches were visited in summer 2012 (July 22-August 26). We note here that all gall collections were made during the same Lipara generation (summer 2012 and winter 2013), minimizing any temporal variability in the data.

The proportion of stems infested with Lipara per $P$. australis patch was estimated for all patches in NA and EU where Lipara were found (Fig. 1). Within each patch, we walked three separate transects from the edge to interior, examining the three closest stems every $2 \mathrm{~m}$ for the presence of a Lipara gall, for a total of 150 stems (50 stems per transect). Patch size (estimated by walking the patch exterior with a handheld GPS or using aerial images for very large patches) and stem density (four replicates of stems per $0.25 \mathrm{~m}^{2}$ quadrat) were also recorded at sites visited in summer 2012. Initial analyses showed that patch size and stem density were unrelated to Lipara infestation (Online Resource 3), so these data were no longer collected in subsequent (winter) surveys or included in later analyses.

\section{Lipara species identity, natural enemies, and performance}

To examine Lipara species composition, parasitism and predation, and performance in native versus invasive $P$. australis patches in NA, galled stems were collected from Lipara-infested patches (Fig. 1). In the summer of 2012,70.1 \pm 8.2 galls (mean $\pm \mathrm{SE}$; range 13-119; number depended on availability) were collected from each of 17 patches ( 9 native, 8 invasive; Online Resource 2). All stems were dissected and Lipara larvae were identified to species (see Chvala et al. 1974) and examined for parasitism. A second collection of galls $(174.0 \pm 11.2$ per patch; range 65-275) was made during late winter of 2013 from 21 patches (11 native, 10 invasive) in order to rear gall inhabitants. As noted previously, galls from this latter collection (winter) represented the same generation of Lipara as the previous (summer) collection. These winter galls were placed in individual Ziploc bags in an environmental chamber $\left(25^{\circ} \mathrm{C}, 95 \% \mathrm{RH}, 16: 8 \mathrm{~h}\right.$ light:dark). Bags were checked weekly and scored based on whether a Lipara adult (identified to species), parasitoid, or predator emerged. Galls exhibiting pecking or chewing damage, and from which no Lipara emerged, were considered to have been successfully depredated by unidentified mammalian or avian predators. If no Lipara emerged, galls were dissected to confirm mortality.

From galls collected in the winter of 2013, L. rufitarsis was the only species reared in sufficient numbers to test differences in performance between native and invasive $P$. australis genotypes. We used dry body mass of emerged adults as a proxy for herbivore performance (see Taylor et al. 1998; Tammaru et al. 2002). For each patch with sufficient numbers, 10 male and 10 female $L$. rufitarsis adults were dried in an oven $\left(60{ }^{\circ} \mathrm{C}\right.$ for $\left.48 \mathrm{~h}\right)$ and weighted to the nearest $0.1 \mathrm{mg}$ using a Mettler microbalance. Ten individuals of each sex were used because single flies were too light to register an accurate measurement on the scale. Mean gall diameter (another measure of larval performance, see Stille 1984; McKinnon et al. 1999; Sopow and Quiring 2001) for each patch visited in the winter of 2013 was estimated from the average maximum diameter of $10 \mathrm{~L}$. rufitarsis galls per patch (measured to the nearest $0.1 \mathrm{~mm}$ ).

\section{Stem height and flowering}

For the most common gall species, L. rufitarsis, we assessed whether galled and non-galled stems differed in stem height and flowering frequency, and how this varied with $P$. australis genotype. At each NA patch visited during the winter of 2013 (11 native, 9 invasive, spanning the known range of Lipara in NA), the heights of 10 galled and 10 non-galled stems, randomly selected along the sampling transects, were measured to the nearest $\mathrm{cm}$. In addition, flowering of non-galled stems was quantified at all sites where Lipara were present by examining 150 random stems along the sampling transects. All galled stems encountered (13 galls minimum, see Online Resource 2) were also scored for presence or absence of flowers. 
Data analysis

We tested whether the Lipara infestation level (proportion of stems infested) per patch differed among the three phylogeographic groups, NA native $(\mathrm{n}=12)$, NA invasive $(\mathrm{n}=14)$, and EU native $(\mathrm{n}=5)$. We only used sites where Lipara was present and the data were analysed using a one-way ANOVA in R version 3.0.3 ( $\mathrm{R}$ Core Team 2014). The distribution of the proportions of stems infested with Lipara galls per patch was normalized using the logit transformation and pairwise differences among phylogeographic groups were assessed with a Tukey's test. To assess whether a particular Lipara species was driving differences in infestation levels we compared Lipara species composition between native and invasive $P$. australis genotypes in NA (composition data were unavailable for EU). To do this we calculated the infestation level of each individual Lipara species as the product of each species' proportional abundance (based on emergences from collected galls) and the proportion of stems infested by all Lipara species combined (from the field census). Infestation levels were compared between native $(\mathrm{n}=12)$ and invasive $(\mathrm{n}=14)$ patches for each Lipara species using a MANOVA with $P$. australis genotype as the categorical variable. The distribution of infestation levels was normalized using the logit transformation.

Predation by vertebrates was compared between Lipara-infested native $(\mathrm{n}=11)$ and invasive $(\mathrm{n}=10) P$. australis patches in NA using a generalized linear model. Whether or not a gall was depredated was the dependent variable with a quasibinomial link function to account for overdispersion (McCullagh and Nelder 1989). P. australis genotype (native, invasive) was a fixed factor, and mean gall diameter and patch size were included as covariates in the model. The model was analyzed using $\mathrm{R}$, which provided $t$-statistics as output. Gall size and patch size are known to influence natural enemies (e.g., Weis and Abrahamson 1986; Morrison et al. 2010, respectively) but have never before been tested with Lipara. We tested for a difference in predation success (the proportion of attacks resulting in the disappearance or death of Lipara) between native and invasive $P$. australis genotypes using a $t$ test.

To assess whether adult $L$. rufitarsis body mass differed between $P$. australis genotypes (11 native, 9 invasive patches), we used a two-way ANCOVA in R.
Genotype and L. rufitarsis sex were fixed factors in the model; the latter was included to account for possible sexual dimorphism within the species. Gall diameter was added as a covariate. Mean diameter of $L$. rufitarsis galls on native and invasive genotypes was also compared using a $t$-test as an additional performance measure.

To examine the potential impact of $L$. rufitarsis on $P$. australis, we tested if the mean height of galled stems was shorter than non-galled stems for both native and invasive genotypes (11 and 9 patches respectively) using $t$ tests. The proportional reduction in stem height [= (galled - non-galled $) /$ non-galled] was also compared between genotypes using a $t$ test to examine if the mean reduction in stem height was greater for native or invasive $P$. australis. Finally, we calculated the impact of Lipara on sexual reproduction at each site as the product of flowering frequency of non-galled stems and the proportion of stems infested by Lipara (from the field survey). Because galled stems always failed to flower, this metric represents the proportional reduction in flowering due to the occurrence of galls. We compared Lipara impact on sexual reproduction between native $(\mathrm{n}=12)$ and invasive $(\mathrm{n}=14)$ genotypes using a $t$ test.

\section{Results}

Lipara distribution and infestation level

Lipara were found only on the east coast of NA between latitudes of $36.5^{\circ}$ and $43.8^{\circ}$, ranging from northern North Carolina to central Maine (Fig. 1). Galls were absent from all other locations. All three Lipara species were found to infest native and invasive $P$. australis genotypes. L. rufitarsis was the most widespread species, and the only species found south of New Jersey. L. similis increased in abundance in northern invasive patches and was the most dominant Lipara species in Massachusetts and Maine. L. pullitarsis was present in only five patches from New Jersey to Connecticut. In Europe, Lipara were present in all countries surveyed (Online Resource 1), ranging from Portugal $\left(40.6^{\circ}\right)$ to Norway $\left(59.3^{\circ}\right)$, but their overall distribution was patchy (present in only 5 of 21 patches surveyed).

Within the occupied range, the overall proportion of $P$. australis stems infested with Lipara differed 
significantly among NA native, NA invasive, and EU native patches $\left(F_{2,28}=25.73, P<0.001\right.$, Figs. 2 , 3a). In native $P$. australis patches, $32.0 \pm 3.9 \%$ (mean $\pm \mathrm{SE}$ ) of stems had a Lipara gall, which was three and 40 times higher than the infestation levels for NA invasive $(10.6 \pm 2.8 \%)$ and EU native $(0.8 \pm 0.1 \%)$ patches, respectively (Figs. 2, 3a, all comparisons $P<0.001$ ). For the European genotypes, the proportion of stems with galls was over thirteen times higher in the invaded range compared to the native range $(P=0.002)$.

Lipara species composition differed significantly between native and invasive genotypes in NA when analysed using MANOVA (Wilks's Lambda $F_{3,22}=3.87, P=0.023$, Fig. 4). This difference in species composition was brought about by $L$. rufitarsis, which was over five times more abundant in native than invasive $P$. australis patches $\left(F_{1,24}=12.04\right.$, $P=0.002$; Fig. 4). $92 \pm 7.7 \%$ of galls collected from native $P$. australis were identified as containing L. rufitarsis, compared to only $67 \pm 20.8 \%$ of the invasive $P$. australis galls. Infestation levels of $L$. similis $\left(F_{1,24}=0.08, P=0.782\right)$ and L. pullitarsis $\left(F_{1,24}=0.01, P=0.946\right)$ did not differ significantly between native and invasive $P$. australis genotypes (Fig. 4).

\section{Lipara parasitism and predation}

Of the 1663 NA galls inspected, we found no evidence of mortality from arthropod parasitoids or predators.

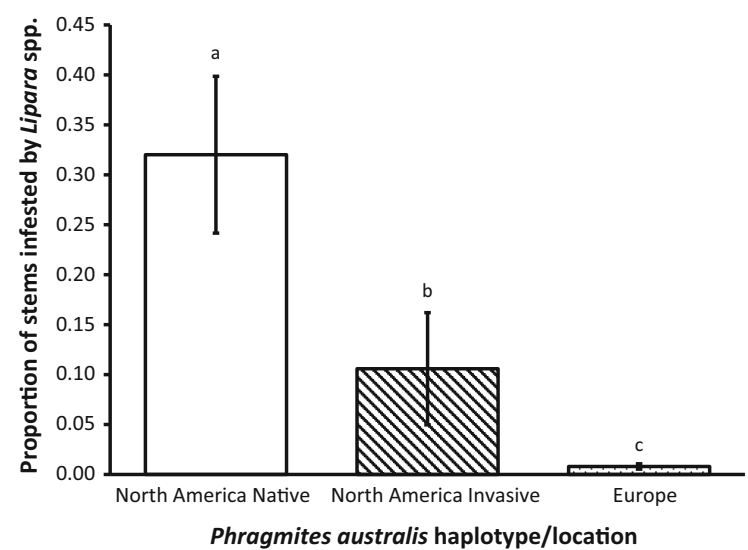

Fig. 2 Mean proportion of stems infested by Lipara $( \pm 95 \%$ CI) in North American native, North American invasive, and European Phragmites australis patches. Different letters indicate significant differences between genotype means $(P<0.05)$ (a) North America

(b) Europe

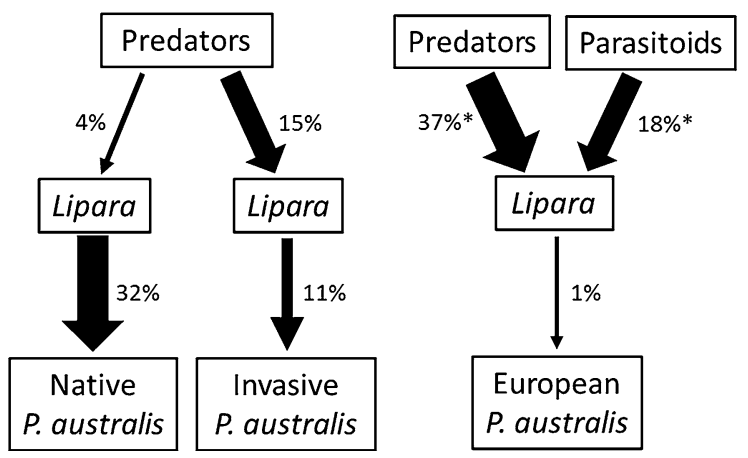

Fig. 3 Schematic diagram illustrating biotic interaction strengths between Phragmites australis, Lipara, and predators/parasitoids of Lipara in North America and Europe, at sites where Lipara were present. Parasitoids were absent in North America. Arrow thickness represents the strength of each interaction, which is also shown by the percentage beside each line (i.e., $\%$ of Lipara galls depredated or parasitized; $\%$ of $P$. australis stems infested by Lipara). *Predation and parasitism of Lipara in Europe is based on an overall average of 25 data points collated from Abraham and Carstensen 1982; Athen and Tsharntke 1999; Tscharntke 1994; Schwarzlander and Hafliger 2000; Reader 2001, 2003 (Online Resource 4)

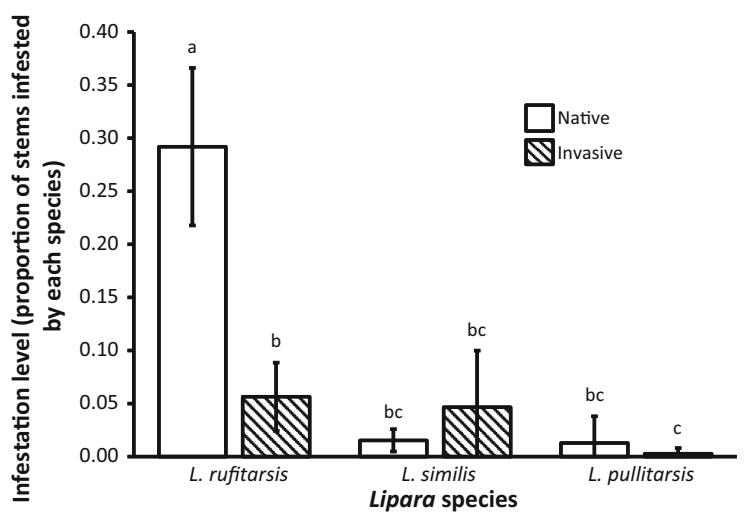

Fig. 4 Mean proportion of collected stems inhabited by each Lipara species $( \pm 95 \% \mathrm{CI})$ in North American native and invasive Phragmites australis patches. Different letters indicate significant differences between means $(P<0.05)$

In contrast, vertebrate predators successfully attacked $14.8 \pm 6.2 \%$ of Lipara galls on the invasive genotype and $3.5 \pm 2.6 \%$ of galls on native genotypes, however this fourfold difference was non-significant ( $t=-0.75, P=0.464$, Figs. 3a, 5a). Gall diameter $(t=-0.68, P=0.684)$ and patch size $(t=0.21$, $P=0.837$ ) were not related to the successful predation level. Not all attacked galls (as evidenced by 
pecking or chewing damage) resulted in the death of the Lipara inhabitant. Seventy $\pm 22.7 \%$ of attacks on galls of invasive genotype and $66 \pm 32.3 \%$ of attacks on native genotypes resulted in the disappearance or death of Lipara; a difference that was non-significant $\left(t_{13}=-0.21, P=0.840\right)$.

\section{Lipara performance}

Dry body mass of L. rufitarsis adults was $13 \%$ higher for individuals reared from native than invasive genotypes, but this result was non-significant $\left(F_{1,35}=0.95, P=0.337\right)$. Female Lipara (2.6 \pm $0.2 \mathrm{mg}$ ) weighed almost twice as much as males $(1.4 \pm 0.1 \mathrm{mg})\left(F_{1,35}=197.34, P<0.001\right)$. A marginally significant positive correlation between the
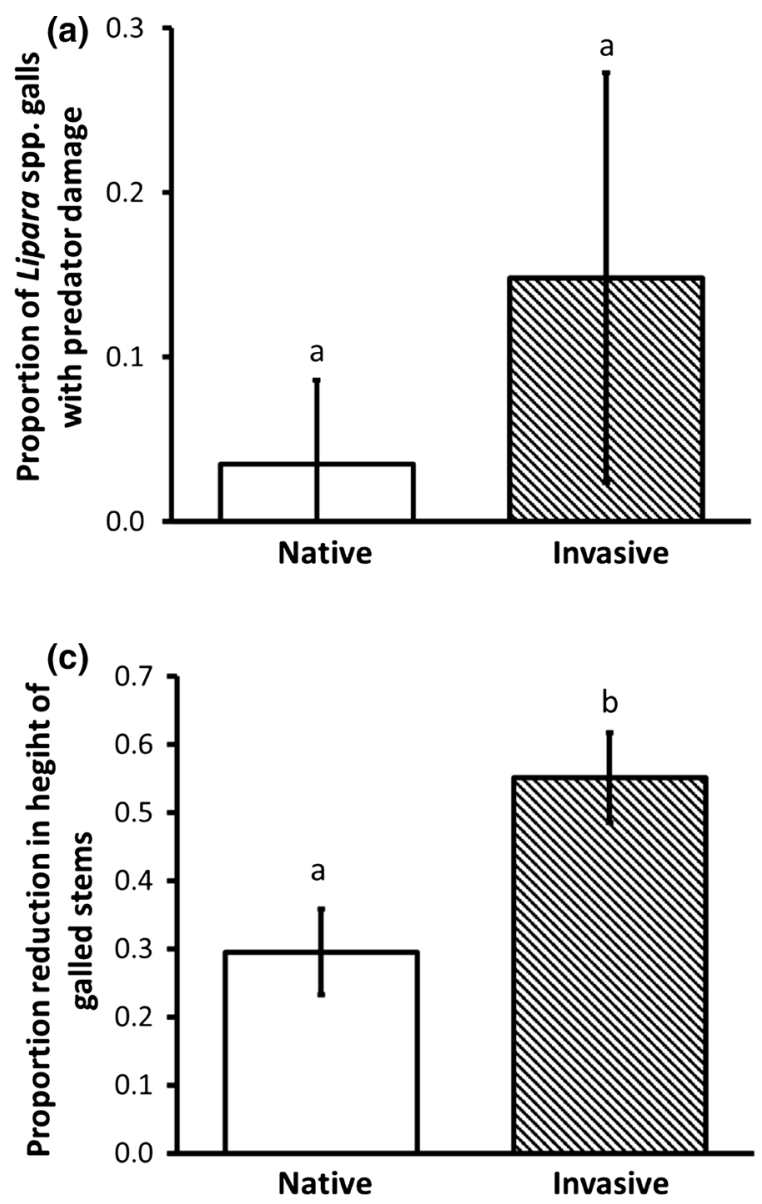

Fig. 5 For native and invasive Phragmites australis genotypes in North America, the a proportion of Lipara galls attacked by mammal or bird predators; $\mathbf{b}$ relationship between gall diameter and dry body mass of $L$. rufitarsis; c proportional reduction in covariate gall diameter and body mass was detected $\left(F_{1,35}=3.48, P=0.071\right.$, Fig. $\left.5 b\right)$. If we removed gall diameter as a covariate in the model, genotype also became significant $\left(F_{1,36}=7.00, P=0.012\right)$ suggesting that differences in Lipara performance between genotypes is due to the effects of genotype on gall size. L. rufitarsis galls were $34 \%$ larger on the native than invasive genotypes $\left(t_{18}=5.75, P<0.001\right.$, Fig. 5b).

\section{P. australis stem heights and flowering}

Stems of the invasive P. australis genotypes with a $L$. rufitarsis gall were $55 \pm 6.6 \%$ shorter than nongalled stems $\left(t_{10}=7.82, P<0.001\right)$. In comparison, native stems with galls were $30 \pm 6.3 \%$ shorter than
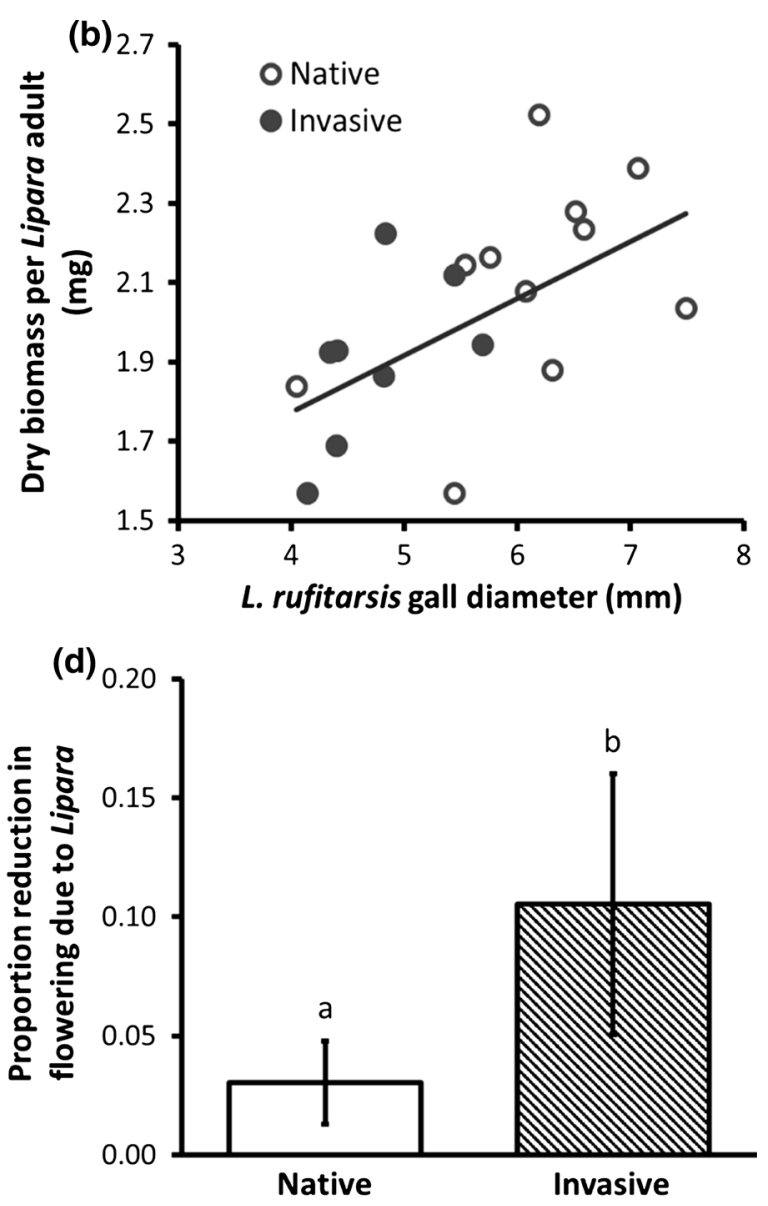

height of stems infested by L. rufitarsis; and $\mathbf{d}$ proportional reduction in flowering frequency due to $L$. rufitarsis. Reported are the means $\pm 95 \%$ CI per patch. Different letters indicate significant differences between genotype means $(P<0.05)$ 
non-galled stems $\left(t_{8}=10.59, P<0.001\right)$. The degree of reduction in stem height when a gall was present was significantly greater for the invasive than native genotype $\left(t_{16}=5.53, P<0.001\right.$, Fig. $\left.5 \mathrm{c}\right)$. No galled stems were observed to have flowered. Invasive $P$. australis genotypes suffered a $10.5 \pm 2.7 \%$ reduction in flowering due to Lipara, almost 3.5 times greater than the $3.0 \pm 0.9 \%$ reduction suffered by native genotypes $\left(t_{24}=-2.43, P=0.023\right.$, Fig. $\left.5 \mathrm{~d}\right)$. However, flowering of non-galled stems was over twofold higher in patches of invasive than native genotypes $\left(t_{24}=-3.03, P=0.006\right)$.

\section{Discussion}

Despite a recent increase in the number of studies involving multi-species introductions into the same community (e.g., Rand and Louda 2004; Lau and Strauss 2005; Dangremond et al. 2010; Green et al. 2011; Stricker and Stiling 2012), our understanding is still limited as to how species interactions change between the native and introduced ranges and the potential implications for invaded native communities. With invasive species expected to become more prevalent (Levine and D'Antonio 2003), it is also likely that trophic interactions involving multiple introduced species will become commonplace. The tritrophic interactions between $P$. australis, Lipara spp. and their natural enemies in EU and NA are summarized in Fig. 3. Support for our first prediction varied regionally; $P$. australis was released from Lipara throughout most of NA (Fig. 1), but our study also showed that along the Atlantic coast the attack of invasive $P$. australis by introduced Lipara species was higher in the novel than ancestral range. Escape from their predators and parasitoids in the introduced range likely allowed Lipara to achieve higher infestation levels (proportion of stems infested) in NA than EU, supporting our third prediction of enemy-release for the gall-forming herbivores. In the novel range, we found that invasive $P$. australis suffered lower attack from the introduced Lipara than closely related native $P$. australis, supporting the local enemy-release hypothesis and our second prediction. Such a result is likely due to a lack of coevolutionary history between native $P$. australis and introduced Lipara, but native predators that cause higher mortality of Lipara on invasive plants could also contribute to the difference in herbivory between native and invasive plants in the novel range. Our study points to the complex interactions that arise when two or more interacting species are introduced into a novel environment, and that a multitrophic framework is required when investigating the influence of biotic interactions on invasion success.

The enemy inversion hypothesis posits that the effects of introduced herbivores on invasive plants may be reduced or even reversed due to novel interactions in their new environment (Pearson et al. 2000; Pearson and Ortega 2002; Colautti et al. 2004). Our study did not support this prediction. Lipara herbivory on European genotypes of $P$. australis was over thirteen times higher in their introduced range (NA) in comparison to their native range (EU). We postulate that the higher infestation level in NA found in our study may be driven by classical enemy-release of Lipara from their EU arthropod predators and parasitoids. The total absence of parasitism in our sampled galls provides stark contrast to parasitism rates in EU previously reported to be $15-26 \%$ for $L$. rufitarsis (Reader 2001, 2003; Tscharntke 1994), $22 \%$ for L. similis (Schwarzlander and Hafliger 2000; Tscharntke 1994), 0-59\% for L. pullitarsis (Abraham and Carstensen 1982; Athen and Tsharntke 1999; Tscharntke 1994), and averaging $18 \%$ across all Lipara species and studies (Fig. 3b, Online Resource 4). Moreover, Nartshuk (2006) reported 33 parasitoid species attacking galls of these Lipara species in EU. We found no evidence that any of these natural enemies of Lipara have been introduced to NA, nor does it seem that native parasitoids have incorporated these novel prey into their host range. Furthermore, predation on Lipara galls by unidentified mammalian or avian predators on the invasive and native $P$. australis genotypes in NA was over two and nine times lower, respectively, than found for Lipara galls in EU where the attack rate averaged $37 \%$ across 3 years (Reader 2001).

Based on our study, the distribution of Lipara in NA is restricted to the Atlantic coast from North Carolina to Maine. This finding expands the known range of Lipara, previously reported as far south as New Jersey (Tewksbury et al. 2002). Moreover, unpublished reports by experts on P. australis (Rohal and Hazelton, pers. comm.) suggest that Lipara (species as yet unidentified) are present in Utah. Given the vast area that $P$. australis covers in NA, it is no surprise that 
Lipara has recently begun appearing in isolated areas further west of its site of arrival on this continent, potentially facilitated by the spread of the invasive genotype. Interestingly, contrary to the report by Blossey (2003), we did find L. pullitarsis infesting stems of native P. australis genotypes. No Lipara were found at any of the surveyed patches north of Yarmouth, Maine $\left(43.8^{\circ}\right.$ ) (Fig. 1; see also Lambert et al. 2007). However, Lipara (species unidentified) were present in Norway during our European survey at a latitude of $59.3^{\circ}$ and are common at high latitudes (Chvala et al. 1974). This distribution suggests Lipara may be able to tolerate colder conditions and that their current northern distribution in NA might not be limited by physiological tolerances. In contrast, physiological tolerances may be limiting the southern extent of Lipara in NA. A single L. similis observation in Israel (approximately $31.7^{\circ}$ ) (Nartshuk 1984) is the only location worldwide in which Lipara has been reported further south than our North Carolina patches $\left(36.5^{\circ}\right)$, suggesting that Lipara may not be tolerant of hotter climates, such as the Gulf Coast region or southwestern United States.

Lipara appear to have considerable impact on $P$. australis sexual reproduction and growth in NA; flowering of infested stems was zero regardless of genotype, suggesting a strong negative effect of Lipara on sexual reproduction of infested stems, which is important to the spread of $P$. australis (Brisson et al. 2008; McCormick et al. 2010). Lipara reduced flowering by $10.5 \%$ for the invasive genotype and $3.0 \%$ for native genotypes, a difference of over threefold. Furthermore, heights of L. rufitarsisinfested stems of native and invasive genotypes were also 30 and $55 \%$ shorter than non-galled stems, respectively (see also Lambert et al. 2007). At present, it is unknown whether L. rufitarsis caused reductions in stem height, or if ovipositing females simply selected stems predisposed to achieving shorter heights. Some support is provided for the latter, as $L$. rufitarsis prefer stems with a small basal diameter (De Bruyn 1993, 1994; Tscharntke 1994), a trait strongly correlated with stem height (Reader 2001). Long-term effects of Lipara and other herbivores on the population-level response of native and invasive $P$. australis genotypes are currently unknown and should be a focus of future research efforts, particularly for potential biological control agents.
We found support for local enemy-release of invasive $P$. australis in the introduced range relative to co-occurring native genotypes. Native $P$. australis genotypes suffered threefold greater herbivory from Lipara than co-occurring invasive genotypes in NA, which was attributed to a fivefold greater infestation level of L. rufitarsis in native compared to invasive patches. The pattern of higher herbivory of native genotypes was consistent with previous studies of three native $P$. australis patches from the northeastern United States (Lambert et al. 2007; Park and Blossey 2008) and is consistent with findings involving other invasive species (e.g., Dietz et al. 2004; Parker and Gilbert 2007; Cincotta et al. 2009; Funk and Throop 2009; Zheng et al. 2012). Cronin et al. (2015) also found that native $P$. australis genotypes in NA suffered greater herbivory from the entire guild of internal feeding herbivores than the invasive genotype, and the same pattern was observed for the widespread and abundant non-native aphid, Hyalopterus pruni, and all chewing herbivores combined. These results suggest that native $P$. australis-inhabited marshes are susceptible to invasion by Lipara and possibly other introduced herbivores. Although invasive $P$. australis suffers lower herbivory compared to native genotypes, this does not fit within the strict definition of enemy-release or biotic-resistance, because Lipara are also introduced to NA. However, the ecological implications of such a pattern on invasion success are the same-an advantage to the invasive plant in its novel range. We suggest that the conceptual framework of enemy-release and bioticresistance be expanded to also include the effects of introduced herbivores, and that further studies are needed examining novel communities inhabited by multiple interacting native and introduced species.

We offer several possible explanations for why Lipara, and possibly other introduced herbivores of $P$. australis, are responsible for greater levels of herbivory on native than invasive genotypes in NA. First, the difference in infestation levels could be explained by the influence of higher trophic levels (i.e., natural enemies; see Fig. 3). We found higher levels of predation by vertebrates on galls of the invasive genotype $(14.8 \%)$ relative to galls of native genotypes $(3.5 \%)$. While this difference was not statistically significant, the large effect size suggests Lipara feeding on native genotypes may be released from 
top-down pressure, whereas invasive $P$. australis may benefit from greater top-down control of herbivores (i.e., a trophic cascade; see Fig. 3). To our knowledge, this study is the first to show that higher trophic levels may impact invasion success in this manner. Second, the invasive genotype has coevolved with Lipara in EU and Asia and may therefore have evolved resistance to attack by Lipara. In contrast, Lipara have only recently been introduced to NA and native genotypes have had little time to adapt defenses to these novel herbivores. For example, the putative defense trait of leaf toughness is greater in invasive than native $P$. australis genotypes (Cronin et al. 2015). Such coevolved plant-herbivore interactions provide bottom-up control of native herbivores, but may allow for outbreaks of newly-associated introduced herbivores (Desurmont et al. 2011; Gandhi and Herms 2009). Thus, a lack of a coevolutionary history with Lipara could result in a lack of specialized defenses with which native $P$. australis genotypes can resist infestation. Furthermore, differences in palatability or nutritional quality may contribute to the difference in herbivory between native and invasive $P$. australis genotypes. Gall diameter and body mass, often indicators of host nutritional quality (e.g., Stille 1984; Taylor et al. 1998; McKinnon et al. 1999; Sopow and Quiring 2001; Tammaru et al. 2002), were $34 \%$ and $13 \%$ higher, respectively, on native than invasive genotypes. Third, previous studies have shown that $L$. rufitarsis is more commonly found infesting $P$. australis shoots with a thin basal diameter (De Bruyn 1993, 1994; Tscharntke 1994). The typically thinner stems of the native genotypes (Lambert et al. 2007) may predispose them to attack by $L$. rufitarsis.

The pattern of greater herbivory on native than invasive genotypes of $P$. australis in NA is emerging as a common phenomenon across multiple species and guilds of introduced herbivores (this paper; Lambert et al. 2007; Lambert and Casagrande 2007; Park and Blossey 2008; Cronin et al. 2015; but see Saltonstall et al. 2014). This trend suggests that Lipara and perhaps other herbivore species may be involved in an invasional meltdown (Simberloff and Von Holle 1999), the process whereby multiple invasive species facilitate one another's spread or exacerbate their impact on native species. Invasive plant species have been shown to facilitate the growth and spread of introduced herbivore populations, leading to negative effects on closely related native plant species via apparent competition (Colautti et al. 2004; Rand and Louda 2004; Lau and Strauss 2005; Dangremond et al. 2010; Lambert and Dudley 2014). Likewise, introduced generalist herbivores can also indirectly facilitate the growth and spread of invasive plant species by preferentially feeding on their native competitors (Parker et al. 2006; Relva et al. 2010). An alternative outcome is invasional antagonism, where invasive species inhibit one another through competition (Belote and Weltzin 2006) or herbivory (La Pierre et al. 2010; Stricker and Stiling 2012). In the situation of $P$. australis, despite the impact of Lipara on sexual reproduction, it is unlikely that Lipara are limiting the spread of invasive $P$. australis due to the plant's rapid clonal growth, high stem density, and greater biomass and flowering frequency relative to native genotypes (see Mozdzer et al. 2013 for review). However, the sheer pervasiveness of the invasive genotypes combined with the escape from parasitoids that Lipara has experienced in NA has possibly facilitated the spread of these herbivores to the relatively rare native $P$. australis genotypes. A key research need is to determine effects of herbivory on competitive outcomes among invasive and native genotypes at the population level, and if the higher relative level of herbivory experienced by native genotypes is contributing to their decline and disappearance in eastern NA.

Acknowledgments Thanks to the stakeholders and landowners who allowed us access: Rachel Carson National Wildlife Refuge, Choptank Nature Conservancy, Palm Beach County Parks Department, Rockefeller Wildlife Refuge, Alice Welford, Mackay Island National Wildlife Refuge, Pettipaug Yacht Club, Sheepscot Valley Conservation Association, and Estell Manor State Park. Thanks also to B. Elderd, R. Andrews, A. Chow, A. Hunt, A. Flora, J. Maynard, H. Baldwin, D. Cummings, J. Anderson, M. Burger, C. Meyerson, M. Meyerson, F. Meyerson, C. Lambertini, and H. Brix for lab and field assistance. We also thank C. Rohal, E. Hazelton, and T. Reader for useful discussion, and the two anonymous reviewers for their comments which improved the quality of this manuscript. This project was funded by NSF grant numbers DEB 1050084 (to J.T.C.) and 1049914 (to L.A.M.), the Louisiana Environmental Education Commission (to W.J.A.), and the University of Rhode Island Agricultural Experiment Station grant number RI00H-332, 311000-6044 (to L.A.M.).

\section{References}

Abraham R, Carstensen B (1982) Die schilfgallen von Liparaarten (Diptera: Chloropidae) und ihre bewohner im schilf der Haseldorfer Marsch bei Hamburg. Entomol Mitt Zool Mus Hambg Bd 7:269-277 
Agrawal AA, Kotanen PM (2003) Herbivores and the success of exotic plants: a phylogenetically controlled experiment. Ecol Lett 6:712-715

Athen O, Tsharntke T (1999) Insect communities of Phragmites habitat used for sewage purification: effect of age and area of habitats on species richness and herbivore-parasitoid interaction. Limnologica 29:71-74

Balme G (2000) Insects on Phragmites australis. Master's thesis. Department of Plant Sciences, University of Rhode Island, Kingston, Rhode Island

Belote RT, Weltzin JF (2006) Interactions between two codominant, invasive plants in the understory of a temperate deciduous forest. Biol Invasions 8:1629-1641

Bhattarai GP, Cronin JT (2014) Hurricane activity and the largescale pattern of spread of an invasive plant species. PLoS One 9:e98478

Blossey B (2003) A framework for evaluating potential ecological effects of implementing biological control of Phragmites australis. Estuaries 26:607-617

Brisson J, Paradis E, Bellavance M (2008) Evidence of sexual reproduction in the invasive common reed (Phragmites australis subsp. australis; Poaceae) in Eastern Canada: a possible consequence of global warming? Rhodora 110:225-230

Castells E, Morante M, Blanco-Moreno JM, Sans FX, Vilatersana R, Blasco-Moreno A (2013) Reduced seed predation after invasion supports enemy release in a broad biogeographical survey. Oecologia 173:1397-1409

Chun YJ, van Kleunen M, Dawson W (2010) The role of enemy release, tolerance and resistance in plant invasions: linking damage to performance. Ecol Lett 13:937-946

Chvala M, Doskocil J, Mook JH, Pokorny V (1974) The genus Lipara Meigen (Diptera: Chloropidae), systematics, morphology, behaviour, and ecology. Tijdschr Entomol 117:1-25

Cincotta CL, Adams JM, Holzapfel C (2009) Testing the enemy release hypothesis: a comparison of foliar insect herbivory of the exotic Norway maple (Acer platanoides L.) and the native sugar maple (A. sacharum L.). Biol Invasions 11:379-388

Clevering OA, Lissner J (1999) Taxonomy, chromosome numbers, clonal diversity and population dynamics of Phragmites australis. Aquat Bot 64:185-208

Colautti RI, Ricciardi A, Grigorovich IA, MacIsaac HJ (2004) Is invasion success explained by the enemy release hypothesis? Ecol Lett 7:721-733

Cronin JT, Bhattarai GP, Allen WJ, Meyerson LA (2015) Biogeography of a plant invasion: plant-herbivore interactions. Ecology 96:1115-1127

Dangremond EM, Pardini EA, Knight TM (2010) Apparent competition with an invasive plant hastens the extinction of an endangered lupine. Ecology 91:2261-2271

Dawson W, Burslem DFRP, Hulme PE (2009) Herbivory is related to taxonomic isolation, but not to invasiveness of tropical alien plants. Divers Distrib 15:141-147

De Bruyn L (1993) Life history strategies of three gall-forming flies tied to natural variation in growth of Phragmites australis. In: Price PW, Mattson WJ, Baranchikov YN (eds) The ecology and evolution of gall-forming insects. United States Department of Agriculture Forest Service, Saint Paul
De Bruyn L (1994) Life cycle strategies in a guild of dipteran gall formers on the common reed. In: Williams M (ed) Plant-galls: organisms, interactions, populations. Clarendon Press, Oxford

De Bruyn L (1995) Plant stress and larval performance of a dipterous gall former. Oecologia 101:461-466

Desurmont GA, Donoghue MJ, Clement WL, Agrawal AA (2011) Evolutionary history predicts plant defense against an invasive pest. PNAS 108:7070-7074

Dietz H, Wirth LR, Buschmann H (2004) Variation in herbivore damage to invasive and native woody plant species in open forest vegetation on Mahé, Seychelles. Biol Invasions 6:511-521

Elton CS (1958) The ecology of invasions by animals and plants. University of Chicago Press, Chicago

Engelkes T, Wouters B, Bezemer TM, Harvey JA, van der Putten WH (2012) Contrasting patterns of herbivore and predator pressure on invasive and native plants. Basic Appl Ecol 13:725-734

Fan S, Yu D, Liu C (2013) The invasive plant Alternanthera philoxeroides was suppressed more intensively than its native congener by a native generalist: implications for the biotic resistance hypothesis. PLoS One 8:e83619

Funk JL, Throop HL (2009) Enemy release and plant invasion: patterns of defensive traits and leaf damage in Hawaii. Oecologia 162:815-823

Gandhi KJK, Herms DA (2009) Direct and indirect effects of alien insect herbivores on ecological processes and interactions in forests of eastern North America. Biol Invasions 12:389-405

Green PT, O’Dowd DJ, Abbott KL, Jeffery M, Retallick K, MacNally R (2011) Invasional meltdown: invader-invader mutualism facilitates a secondary invasion. Ecology 92:1758-1768

Grochowska M (2013) Morphology of preimaginal stages of Lipara lucens (Diptera, Chloropidae) - a gall-forming fly in the common reed (Phragmites australis). Acta Zool 94:94-100

Hansen RM (1978) Shasta ground sloth food habits, Rampart Cave, Arizona. Paleobiology 4:302-319

Harvey JA, Bukovinszky T, van der Putten WH (2010) Interactions between invasive plants and insect herbivores: a plea for a multitrophic perspective. Biol Conserv 143:2251-2259

Hauber DP, Saltonstall K, White DA, Hood CS (2011) Genetic variation in the common reed, Phragmites australis, in the Mississippi River Delta marshes: evidence for multiple introductions. Estuar Coast 34:851-862

Hill SB, Kotanen PM (2009) Evidence that phylogenetically novel non-indigenous plants experience less herbivory. Oecologia 161:581-590

Howard R, Travis JSE, Stiles BA (2008) Rapid growth of a Eurasian genotype of Phragmites australis in a restored brackish marsh in Louisiana, USA. Biol Invasions 10:369-379

Keane RM, Crawley MJ (2002) Exotic plant invasions and the enemy release hypothesis. Trends Ecol Evol 17:164-170

Kulmatiski A, Beard KH, Meyerson LA, Gibson JC, Mock KE (2010) Nonnative Phragmites australis invasion into Utah wetlands. West N Am Nat 70:541-552

La Pierre KJ, Harpole WS, Suding KN (2010) Strong feeding preference of an exotic generalist herbivore for an exotic 
forb: a case of invasional antagonism. Biol Invasions 12:3025-3031

Lambert AM, Casagrande RA (2007) Susceptibility of native and non-native common reed to the non-native mealy plum aphid (Homoptera: Aphididae) in North America. Environ Entomol 36:451-457

Lambert AM, Dudley TL (2014) Exotic wildland weeds serve as reservoirs for a newly introduced cole crop pest, Bagrada hilaris (Hemiptera: Pentatomidae). J Appl Entomol 138(10):795-799

Lambert AM, Winiarski K, Casagrande RA (2007) Distribution and impact of exotic gall flies (Lipara sp.) on native and exotic Phragmites australis. Aquat Bot 86:163-170

Lambertini C, Mendelsshon I, Gustafsson MGH, Olesen B, Riis T, Sorrell BK, Brix H (2012) Tracing the origin of Gulf Coast Phragmites (Poaceae)—a story of long distance dispersal and hybridization. Am J Bot 99:538-551

Lau JA, Strauss SY (2005) Insect herbivores drive important indirect effects of exotic plants on native communities. Ecology 86:2990-2997

Levine JM, D'Antonio CM (2003) Forecasting biological invasions with increasing international trade. Conserv Biol $17: 322-326$

Liu H, Stiling P (2006) Testing the enemy release hypothesis: a review and meta-analysis. Biol Invasions 8:1535-1545

McCormick MK, Kettenring KM, Baron HM, Whigham DF (2010) Extent and reproductive mechanisms of Phragmites australis spread in brackish wetlands in Chesapeake Bay, Maryland (USA). Wetlands 30:67-74

McCullagh P, Nelder JA (1989) Generalized linear models, 2nd edn. Chapman and Hall, London

McKinnon ML, Quiring DT, Bauce E (1999) Influence of tree growth rate, shoot size and foliar chemistry on the abundance and performance of a galling adelgid. Funct Ecol 13:859-867

Meadows RE, Saltonstall K (2007) Distribution of native and introduced Phragmites australis in freshwater and oligohaline tidal marshes of the Delmarva Peninsula and southern New Jersey. J Torrey Bot Soc 134:99-107

Menéndez R, González-Megías A, Lewis OT, Shaw MR, Thomas CD (2008) Escape from natural enemies during climate-driven range expansion: a case study. Ecol Entomol 33:413-421

Meyerson LA, Cronin JT (2013) Evidence for multiple introductions of Phragmites australis to North America: detection of a new non-native genotype. Biol Invasions 15:2605-2608

Meyerson LA, Saltonstall K, Windham L, Kiviat E, Findlay S (2000) A comparison of Phragmites australis in freshwater and brackish environments in North America. Wetl Ecol Manag 8:89-103

Meyerson LA, Saltonstall K, Chambers RM (2009) Phragmites australis in eastern North America: a historical and ecological perspective. In: Silliman BR, Grosholz E, Bertness MD (eds) Human impacts on salt marshes: a global perspective. University of California Press, Los Angeles

Meyerson LA, Lambertini C, McCormick MK, Whigham DF (2012) Hybridization of common reed in North America? The answer is blowing in the wind. AoB Plants. doi:10. 1093/aobpla/pls022
Mitchell CE, Power AG (2003) Release of invasive plants from fungal and viral pathogens. Nature 421:625-627

Mook JH (1967) Habitat selection by Lipara lucens Mg. (Diptera, Chloropidae) and its survival value. Arch Neerlandaises Zool 17:469-549

Morrison WE, Hay ME (2011) Herbivore preference for native vs. exotic plants: generalist herbivores from multiple continents prefer exotic plants that are evolutionarily naïve. PLoS One 6:e17227

Morrison EB, Lindell CA, Holl KD, Zahawi RA (2010) Patch size effects on avian foraging behavior: implications for tropical forest restoration design. J Appl Ecol 47:130-138

Mozdzer TJ, Brisson J, Hazelton ELG (2013) Physiological ecology and functional traits of North America native and Eurasian introduced Phragmites australis lineages. AOB Plants. doi:10.1093/aobpla/plt048

Nartshuk EP (1984) Family Chloropidae. In: Soos A (ed) Catalogue of Palaearctic Diptera, vol 10. Akademiai Kiado, Budapest

Nartshuk EP (2006) Parasites of grass flies (Diptera, Chloropidae) from the order Hymenoptera in the Holarctic region. Entomol Rev 86:576-597

Nartshuk EP (2007) Gall forming Lipara Meigen (Diptera: Chloropidae) on reed (Phragmites australis) and their inquilines and parasites in the eastern European plains. Povolz Ecol J 3:206-214

Orson RA (1999) A paleoecological assessment of Phragmites australis in New England tidal marshes: changes in plant community structure during the last few millennia. Biol Invasions 1:149-158

Park MG, Blossey B (2008) Importance of plant traits and herbivory for invasiveness of Phragmites australis (Poaceae). Am J Bot 95:1557-1568

Parker IM, Gilbert GS (2007) When there is no escape: the effects of natural enemies on native, invasive, and nonnative plants. Ecology 88:1210-1224

Parker JD, Hay ME (2005) Biotic resistance to plant invasions? Native herbivores prefer non-native plants. Ecol Lett 8:959-967

Parker JD, Burkepile DE, Hay ME (2006) Opposing effects of native and exotic herbivores on plant invasions. Science 311:1459-1461

Pearson DE, Ortega YK (2002) Evidence of an indirect dispersal pathway for spotted knapweed, Centaurea maculosa, seeds, via deer mice, Peromyscus maniculatus, and great horned owls, Bubo virginianus. Can Field Nat 115:354

Pearson DE, McKelvey KS, Ruggiero LF (2000) Non-target effects of an introduced biological control agent on deer mouse ecology. Oecologia 122:121-128

Prior KM, Hellmann JJ (2013) Does enemy loss cause release? A biogeographical comparison of parasitoid effects on an introduced insect. Ecology 94:1015-1024

R Core Team (2014) R: a language and environment for statistical computing. Version 3.0.3. R Foundation for Statistical Computing, Vienna, Austria

Rand TA, Louda SM (2004) Exotic weed invasion increases the susceptibility of native plants to attack by a biocontrol herbivore. Ecology 85:1548-1554

Reader T (2001) Competition, kleptoparasitism and intraguild predation in a reedbed community. PhD dissertation. Darwin College, Cambridge University, UK 
Reader T (2003) Strong interactions between species of phytophagous fly: a case of intraguild kleptoparasitism. Oikos 103:101-112

Relva MA, Nuñez MA, Simberloff D (2010) Introduced deer reduce native plant cover and facilitate invasion of nonnative tree species: evidence for invasional meltdown. Biol Invasions 12:303-311

Sabrosky CW (1958) A Phragmites gall-maker new to North America (Diptera, Chloropidae). P Entomol Soc Wash 60:231

Saltonstall K (2002) Cryptic invasion by a non-native genotype of Phragmites australis into North America. PNAS 99:2445-2449

Saltonstall K, Castillo HE, Blossey B (2014) Confirmed field hybridization of native and introduced Phragmites australis (Poaceae) in North America. Am J Bot 101:211-215

Schwarzlander M, Hafliger P (2000) Shoot flies, gall midges, and shoot and rhizome mining moths associated with common reed in Europe and their potential for biological control. In: Spencer NR (ed) Proceedings of the 10th international symposium on biological control of weeds. Montana State University, Bozeman

Simberloff D, Von Holle B (1999) Positive interactions of nonindigenous species: invasional meltdown? Biol Invasions 1:21-32

Skuhravy V (1981) Invertebates and vertebrates attacking common reed stands (Phragmites communis) in Czechoslovakia. Czechoslovak Academy of Sciences, Prague

Sopow SL, Quiring DT (2001) Is gall size a good indicator of adelgid fitness? Entomol Exp Appl 99:267-271

Stille B (1984) The effect of hostplant and parasitoids on the reproductive success of the parthenogenetic gall wasp $D i$ plolepis rosae. Oecologia 63:364-369
Stricker KB, Stiling P (2012) Herbivory by and introduced Asian weevil negates population growth of an invasive Brazilian shrub in Florida. Ecology 93:1902-1911

Tammaru T, Esperk T, Castellanos I (2002) No evidence for costs of being large in females of Orgyia spp. (Lepidoptera, Lymantriidae): larger is always better. Oecologia 133:430-438

Taylor BW, Anderson CR, Peckarsky BL (1998) Effects of size at metamorphosis on stonefly fecundity, longevity, and reproductive success. Oecologia 114:494-502

Tewksbury L, Casagrande R, Blossey B, Häfliger P, Schwärzlander M (2002) Potential for biological control of Phragmites australis in North America. Biol Control 23:191-212

Tscharntke T (1994) Tritrophic interactions in gallmaker communities on Phragmites australis: testing ecological hypotheses. In: Price PW, Mattson WJ, Baranchikov YN (eds) The ecology and evolution of gall-forming insects. United States Department of Agriculture Forest Service, Saint Paul

Vachon N, Freeland JR (2011) Phylogeographic inferences from chloroplast DNA: quantifying the effects of mutations in repetitive and non-repetitive sequences. Mol Ecol Resour 11:279-285

Weis AE, Abrahamson WG (1986) Evolution of the host-plant manipulation by gall makers: ecological and genetic factors in the Solidago-Eurosta system. Am Nat 127:681-695

Wolfe LM (2002) Why alien invaders succeed: support for the escape-from-enemy hypothesis. Am Nat 160:705-711

Zheng YL, Feng YL, Wang RF, Shi XD, Lei YB, Han LH (2012) Invasive Eupatorium adenophorum suffers lower enemy impact on carbon assimilation than native congeners. Ecol Res 27:867-872 